\title{
Relation between Suppressiveness to Tomato Fusarium Wilt and Microbial Populations in Different Growth Media
}

\author{
C. Borrero, M.J. Infantes, E. González \\ and M. Avilés \\ Dept. Ciencias Agroforestales, E.U.I.T.A. \\ Universidad de Sevilla. Ctra Utrera, km \\ $1, \mathrm{~s} / \mathrm{n} 41013$ Sevilla \\ Spain
}

\author{
J.C. Tello \\ Dept. Producción Vegetal, Universidad \\ de Almería. Ctra. Sacramento s/n, 04120 \\ La Cañada de San Urbano, Almería \\ Spain
}

Keywords: Composts, biocontrol, coir fibre, peat, Fusarium oxysporum

\begin{abstract}
Tomato Fusarium wilt suppressiveness of three growth media, with respect to peat and vermiculite, and the relationship between microbial populations of growth media in the severity of this pathogen were examined. The growth media evaluated were olive oil husk + cotton gin trash composted and mixed with rice husk $(\mathrm{OC}+\mathrm{R})$, spent mushroom composted and mixed with peat $(\mathrm{SM}+\mathrm{P})$ and coir fibre. To determine the role of the microflora in the suppression, the two composts were also heated to $60^{\circ} \mathrm{C}$ for 6 days. Three bioassays were carried out with these infested growth media and controls not infested. Disease severity was recorded during 25 days after tomato seedling transplantation. In these seven growth media the density of culturable groups of microorganisms was determined by dilution plating on semi-selective media before the bioassays. The two composts showed suppressiveness to Fusarium wilt with respect to vermiculite and peat while coir fibre was conductive. Furthermore, in OC+R its suppressiveness is due more to the growth media's non heat-labile properties than in SM+P. Significant negative correlations were found between severity and Bacillus spp., cellulolytic actinomycetes and bacteria, oligotrophic actinomycetes and bacteria, copiotrophic bacteria, total actinomicetes (cellulolytic + oligotrophic + copiotrophic) and total bacteria (cellulolytic + oligotrophic + copiotrophic) populations in these growth media. Bacillus spp. are known antagonists, so they may account for the suppressiveness in our composts. Cellulolytic and oligotrophic actinomycete populations were associated with Fusarium wilt suppressiveness for another growth media. High microbial activity has been reported as a Fusarium wilt suppressiveness factor. Copiotrophic, celullolitic and oligotrophic bacteria contribute to this microbial activity.
\end{abstract}

\section{INTRODUCTION}

Tomato production with intensive systems in Spain is increasingly using potting culture with organic substrates. One of the tomato crop problems is Fusarium wilt which cause important yield losses, and for these problems there are no effective chemical control measures. However, biological control is becoming an efficient alternative for controlling these diseases. Some growth media formulated with composts are able to suppress Fusarium wilt with respect to peat (Chef et al., 1983; Orlikowski, 1983; Trillas-Gay et al., 1986; Garibaldi, 1988; Pera and Calvet, 1989; Hoitink et al., 1991; Serra-Wittling et al., 1996; Szczech, 1999; Cotxarrera et al., 2002; Reuveni et al., 2002; Trillas et al., 2002). The nature of soils and composts with suppressiveness to Fusarium wilt is the result of complex interactions between the abiotic characteristics of the media and microbial populations (Hoitink et al., 1993; Alabouvette et al., 1996; Weller et al., 2002; Borrero et al., 2004b). Several biocontrol agents have been identified in these soils and composts (Hoitink et al., 1993; Weller et al., 2002). The microbiological nature of Fusarium wilt suppressiveness for many compost-amended growth media has been demonstrated previously (Chef et al., 1983; Orlikowski, 1983; Trillas-Gay et al., 1986; Garibaldi, 1988; Hoitink et al., 1991; SerraWittling et al., 1996; Szczech, 1999; Cotxarrera et al., 2002; Reuveni et al., 2002; Trillas et al., 2002). The suppressiveness to soilborne plant pathogenic fungi mechanisms involve general suppression, which is related to high microbial activity, and specific suppression, which is related to an increase in the population of specific microorganisms or groups of microorganisms that act as antagonists to the pathogen (Cook and Baker, 1983). On the other 
hand, general disease suppression can be dependent on communities of microorganisms. These communities may be associated with a substrate at a particular stage of decomposition under certain environmental and management conditions (Boehm et al., 1993, 1997). The composition of functional groups (rather than individual species) may determine the character of the community while individual species within a functional group may be interchangeable (van Bruggen and Semenov, 2000). The aims of this research were to evaluate three growth media Fusarium wilt suppressiveness with respect to peat and vermiculite and to study the relationship between microbial populations of growth media on the severity of Fusarium wilt in order to predict disease suppressiveness of growth media.

\section{MATERIAL AND METHODS}

\section{Plant Growth Media}

Two composted residues from agricultural and industrial wastes and fertilized coir fibre (Cocopeat, Projar, Valencia, Spain) were evaluated for Fusarium wilt suppression. The growth media made with composts were olive oil husk + cotton gin trash, 1:1 v/v, composted and mixed with rice husk $(1: 1 \mathrm{v} / \mathrm{v})(\mathrm{OC}+\mathrm{R})$, and spent mushroom composted (Recomsa, Quintanar del Rey, Spain) mixed with light peat $(1: 1 \mathrm{v} / \mathrm{v})(\mathrm{SM}+\mathrm{P})$. The $\mathrm{OC}+\mathrm{R}$ was composted as described elsewhere (Trillas et al., 2002). Fertilized light peat (Klasmann, Valinex, Palleter, Spain) and vermiculite (Vermiculita y derivadas, Gijón, Spain) was used as a reference. Peat was neutralized with $4 \mathrm{~g} \mathrm{~L}^{-1} \mathrm{CaCO}_{3}$. Fertilized peat and coir fibre had $0.33 \mathrm{~g}$ $\mathrm{L}^{-1}$ of $\mathrm{K}_{2} \mathrm{O}(50 \%$ high solubility granulated; Compo Agricultura S.L., Barcelona, Spain) and $4.15 \mathrm{~g} \mathrm{~L}^{-1}$ of $\mathrm{P}_{2} \mathrm{O}_{5}$ (18\% granulated; Fertiberia, Madrid, Spain). Plant growth media made with composts were not fertilized. To standardize initial conditions, the growth media were incubated at a water tension of $1000 \mathrm{~Pa}$ (adjusted for weight) for 14 days at $25^{\circ} \mathrm{C}$. To determine the role of microflora in suppression, the two composts were also heated to $60^{\circ} \mathrm{C}$ for 6 days $(\mathrm{OC}+\mathrm{R} 60$ and $\mathrm{SM}+\mathrm{P} 60)$.

\section{Assessment of Disease Severity}

Disease suppressive properties of growth media were measured by a Fusarium wilt bioassay described elsewhere (Cotxarrera et al., 2002). The bioassays were developed with tomato 'Roma' and a monosporic isolate of Fusarium oxysporum $\mathrm{f}$. sp. lycopersici race 2 (FOL-2). This isolate was obtained from tomato plants and stored in silica gel. Liquid culture, $500 \mathrm{ml}$ 1\% malt extract (Sigma Chemical Company, St Louis, MO), of FOL-2 was prepared and grown with continuous agitation $(130 \mathrm{rpm})$ for 10 days at $25^{\circ} \mathrm{C}$. Conidia were recovered after filtration and centrifugation at $5000 \mathrm{rpm}, 15 \mathrm{~min}$, (Eppendorf $5810 \mathrm{R}$, Hamburg, Germany) and rinsed twice with sterile distilled water. The concentration of conidia was determined with a hemocytometer. The seven growth media were infested with FOL-2 $\left(10^{5}\right.$ microconidia $\mathrm{ml}^{-1}$ growth media), mixed vigorously and poured into $9 \mathrm{~cm}$ diameter plastic pots $(330 \mathrm{ml}$ volume). Non infested growth media were used as controls. Four tomato seedlings ( 1 to 2 true leaf stage) grown in vermiculite were transplanted into each pot. Plants were irrigated as needed and fertilized with Peter's foliar feed 27-15-12 (Scotts Heerlen, The Netherlands), $0.5 \mathrm{~g} \mathrm{~L}^{-1}$ enriched with $0.6 \mathrm{~g} \mathrm{~L}^{-1}$ of $\mathrm{CaCl}_{2}, 0.696 \mathrm{~g} \mathrm{~L}^{-1} \mathrm{MgSO}_{4} .7 \mathrm{H}_{2} \mathrm{O}$ and $0.3 \mathrm{~g}$ $\mathrm{L}^{-1}$ of urea $(46 \%)$. They were grown in a growth chamber $\left(27^{\circ} \mathrm{C}, 280 \mu \mathrm{E} / \mathrm{m} 2 / \mathrm{s}\right.$ PAR intensity, 16:8 h light:dark photoperiod and 60\% RH). Disease severity was monitored for 25 days after planting and was scored every two days based on a symptom severity scale where: $0=$ asymptomatic plants; $1=$ weakly infected plants ( $\leq 50 \%$ of leaves chlorotic or wilted); $2=$ highly infected plants $(>50 \%$ of leaves wilted but plants not dead) and $3=$ dead plants (Cotxarrera et al., 2002). The area-under-the-disease-progress-curve (AUDPC) was calculated, and AUDPCs was also calculated by dividing AUDPC by the total time duration (days) of the epidemic of each bioassay for comparison between epidemics in different bioassays (Campbell and Madden, 1990). These bioassays were repeated at least three times with five pots per treatment. At each rating time, the mean of the disease severity and the percentage of symptomatic plants per pot were calculated. This mean was considered as one value. Treatments were arranged in a randomized block design.

\section{Microbial Populations}


The density of cultivable groups of bacteria and fungi associated with biocontrol phenomena was determined by dilution plating on semi-selective media according to Tuitert et al. (1998) with modifications. Samples were taken from incubated plant growth media before the bioassays. Plant growth media (5 to10 g) were suspended in $250 \mathrm{ml}$ of $0.1 \%$ sodium pyrophosphate. The suspension was shaken and tenfold dilution series were prepared with $0.1 \%$ water agar. Suspensions were pipetted onto three plates per culture medium and dilution. Four or five dilutions per series were placed on plates. For isolation of Bacillus spp., fluorescent Pseudomonas spp., copiotrophic, oligotrophic and cellulolytic bacteria and actinomycetes, $100 \mu \mathrm{g} \mathrm{ml}^{-1}$ of cycloheximide was substituted for $10 \mu \mathrm{g} \mathrm{ml}^{-1}$ of benomyl (Energía e Industrias Aragonesas, S.A., Madrid) and $0.3 \mu \mathrm{ml}^{-1}$ of Previcur (Propamocarb, $72.2 \%$, Schering, Alcácer, Spain). Fungal counts were made on potato dextrose agar amended with 1,000 ppm of Tergitol-7 (Fluka Chemie AGB, Buchs, Switzerland) and $50 \mu \mathrm{g} \mathrm{ml}^{-1}$ of oxytetracycline hydrochloride (Sigma Chemical Company, St Louis, MO) (Chen et al., 1988). Analyses were performed three times with one sample per each control plant growth medium from each of the three bioassays.

\section{Statistical Analysis}

Data collected from all trials were analyzed with Statgraphics Plus, Version 6 (SGS, 1999). The effect of the growth medium on the AUDPCs was analyzed with ANOVA. Significant means were compared by Tukey's whole significant difference test $(P=0.05)$. Overall relationships between AUDPCs and the microorganism populations of the plant growth media were analyzed with regression analysis.

\section{RESULTS AND DISCUSSION}

The two composts with and without heat treatment showed a lesser severity than vermiculite, peat and coir fibre (Fig. 1). These results indicated that the two composts had suppressive characteristics to Fusarium wilt with respect to the reference growth media, while the coir fibre was conductive. Furthermore, $\mathrm{OC}+\mathrm{R}$ suppressiveness is due more to the growth media's non heat-labile properties than in $\mathrm{SM}+\mathrm{P}$ (Fig. 1). In this sense, preliminary data were exposed by Borrero et al. (2002 and 2004a). These growth media non heat-labile properties can be physical and chemical factors or the microbial populations recovered from a heat treatment after a few days. These non heat-labile properties can facilitate a fast microbial population recuperation, which could raise microbial activity, associated with general suppression (Weller et al., 2002). On the other hand, antagonists populations can be destroyed by the heat treatment. This indicates that $\mathrm{OC}+\mathrm{R}$ suppressiveness can be due to general suppression and $\mathrm{SM}+\mathrm{P}$ suppression can be due to general and specific suppression. This general suppression can be accompanied by thermophilic antagonist specific suppression, due to their resistance to the heat treatment.

Significant negative correlations were found between severity and Bacillus spp., cellulolytic actinomycetes and bacteria, oligotrophic actinomycetes and bacteria, copiotrophic bacteria, total actinomicetes (cellulolytic + oligotrophic + copiotrophic) and total bacteria (cellulolytic + oligotrophic + copiotrophic) populations in these growth media (Table 1). On the other hand no significative correlations were encountered between severity and Pseudomonas and fungi densities (data not shown).

The high population levels of Bacillus spp. associated with the two composts, either natural or heated, are due to the high composting temperatures that select thermophilic microorganisms. They are known antagonists to Fusarium wilt (Khan and Khan, 2001), so they may account for the suppressiveness in our composts.

One of the most important groups containing antagonistic microorganisms is the group of fluorescent pseudomonads (Garbeva et al., 2004). Although, it seems that these bacteria are not a main factor for suppressiveness in our composts or, at least, fluorescent pseudomonads density is not a good predictive parameter. Root exudates supply nutrients that promote high growth rates of pseudomonads (Garbeva et al., 2004), that can be the cause of the lack of correlation between severity and pseudomonads populations before planting.

With other composts rhizosphere fungi density has been negatively correlated with Fusarium wilt severity (Borrero et al., 2004b). This indicates that fungi are not very important in these composts suppressiveness, at least at the beginning of the crop. 
Cellulolytic and oligotrophic actinomycetes rizosphere populations were associated to Fusarium wilt suppressiveness for other growth media (Borrero et al., 2004b). Total number of actinomycetes also was positively correlated with suppression of corky root of tomato (Workneh and van Bruggen, 1994). Therefore, actinomycete densities can be a good predictive plant growth media suppressiveness parameter. High microbial activity has been reported as a Fusarium wilt suppressiveness factor (Borrero et al., 2004b). Therefore, high bateria densities (copiotrophic, celullolitic and oligotrophic) contribute to Fusarium wilt suppressiveness. On the other hand, oligotrophic organisms and a low ratio oligotrophic bacteria / copiotrophic bacteria have been associated with conductiveness (Hoitink et al., 1996; Borrero et al., 2004b). The plant growth media made with compost are mixed with materials with low biodegradable components (rice husk and peat). These materials supported oligotrophic populations. Therefore, the negative correlation between the severity and oligotrophic bacteria resembles their microbial activity. This indicates the general suppression importance in these plant growth media. Therefore, oligotrophic bacteria densities are not a reliable suppressiveness parameter.

\section{Literature Cited}

Alabouvette, C. 1986. Fusarium-wilt suppressive soils from the Châteaurenard region: review of a 10-year study. Agronomie 6:273-284.

Alabouvette, C., Hoeper, H., Lemanceau, P. and Steinberg, C. 1996. Soil suppressiveness to diseases induced by soilborne plant pathogens. p.371-413. In: G. Stotzky, and J.M. Bollag (eds.), Soil Biochemistry, Vol 9, Marcel Dekker, Inc, New York.

Boehm, M.J., Madden, L.V. and Hoitink, H.A.J. 1993. Effect of organic matter decomposition level on bacteria species diversity and composition in relationship to Pythium damping-off severity. Appl. Environ. Microbiol. 59:4171-4179.

Boehm, M.J., Wu, T., Stone, A.G., Kraakman, B., Iannotti, D.A., Wilson, G.E., Madden, L.V. and Hoitink, H.A.J. 1997. Cross-polarized magic-anglespinning 13C nuclear magnetic resonance spectroscopic characterization of soil organic matter relative to culturable bacterial composition and sustained biological control of Pythium root rot . Appl. Environ. Microbiol. 63:162-168.

Borrero, C., Infantes, M.J., Castillo, S. and Avilés, M. 2004a. Supresividad de un sustrato formulado con un compost del residuo del cultivo del champiñón y conductividad de la fibra de coco frente a la fusariosis vascular del tomate. VII Jornadas de Sustratos de la SECH. Madrid, Spain. Abstract.

Borrero, C., Tello, J.C. and Avilés, M. 2002. Supresividad de un sustrato a base de compost de alperujo y cascarilla de arroz frente a la fusariosis vascular del tomate. VI Jornadas de Sustratos de la SECH. Barcelona, Spain. Abstract.

Borrero, C., Trillas, M.I., Ordovás, J., Tello, J.C. and Avilés, M. 2004b. Predictive factors for the supression of Fusarium wilt of tomato in plant growth media. Phytopathology 94: 1094-1101.

Campbell, C.L. and Madden, L.V. 1990. Introduction to plant disease epidemiology. Ed. Wiley Interscience, U.S.A.

Chef, D.G., Hoitink, H.A.J. and Madden, L.V. 1983. Effects of organic components in container media on suppression of Fusarium wilt of chrysanthemum and flax. Phytopathology 73:279-281.

Chen, W., Hoitink, H.A.J, Schmitthenner, A.F. and Tuovinen, O.H. 1988. The role of microbial activity in suppression of damping-off caused by Pythium ultimum. Phytopathology 78:314-322.

Cook, R.J. and Baker, K.F. 1983. The nature and practice of biological control of plant pathogens.Third printing Ed. APS Press, St. Paul, Minnesota.

Cotxarrera, L., Trillas-Gay, M.I., Steinberg, C. and Alabouvette, C. 2002. Use of sewage sludge compost and Trichoderma asperellum isolates to suppress Fusarium wilt of tomato. Soil Biol. Biochem. 34:467-476.

Garbeva, P., van Veen, J.A. and van Elsas, J.D. 2004. Microbial diversity in soil: selection of microbial populations by plant and soil type and implications for disease suppressiveness. Annu. Rev. Phytopathol. 42:243-270.

Garibaldi, A. 1988. Research on substrates suppressive to Fusarium oxysporum and Rhizoctonia solani. Acta Hort. 221:271-277. 
Hoitink, H.A.J., Boehm, M.J. and Hadar, Y. 1993. Mechanisms of suppression of soilbome plant pathogens in compost-amended substrates. p. 601-621. In: H.A.J. Hoitink and H.M. Keener (eds.), Science and Engineering of Composting: Design, Environmental, Microbiological and Utilization Aspects. Renaissance Publications, Worthington, $\mathrm{OH}$.

Hoitink, H.A.J., Inbar, Y. and Boehm, M.J. 1991. Status of compost-amended potting mixes naturally suppressive to soilborne diseases of floricultural crops. Plant Dis. 75:869-873.

Hoitink, H.A.J., Madden, L.V. and Boehm, M.J. 1996. Relationships among organic matter decomposition level, microbial species diversity and soilborne disease severity. p. 237249. In: R. Hall (ed.), Principles and practice of managing soilborne plant pathogens, A.P.S. Press, St. Paul, MN.

Khan, M.R. and Khan, S.M. 2001. Biomanagement of Fusarium wilt of tomato by the soil application of certain phosphate-solubilizing microorganisms. Int. j. pest. manag. 47(3): 227-231.

Orlikowski, L.B. 1983. Influence of substratum type and fungicidal treatment on the development of Fusarium wilt of carnation. Acta Hort. 150:127-139.

Pera, J. and Calvet, C. 1989. Suppression of Fusarium wilt of carnation in a composted pine bark and composted olive pumice. Plant Dis. 73:699-700.

Reuveni, R., Raviv, M., Krasnovsky, A., Freiman, L., Medina, S., Bar, A. and Orion, D. 2002. Compost induces protection against Fusarium oxysporum in sweet basil. Crop Prot. 21:583-587.

Serra-Wittling, C., Houot, S. and Alabouvette, C. 1996. Increased soil suppressiveness to Fusarium wilt of flax after addition of municipal solid waste compost. Soil Biol. Biochem. 28:1207-1214.

Szczech, M.M. 1999. Suppressiveness of vermicompost against Fusarium wilt of tomato. J. Phytopathol. 147:155-161.

Trillas, I., Avilés, M., Ordovás, J., Bello, A. and Tello, J.C. 2002. Using compost as a methyl bromide alternative. Biocycle 43:64-68.

Trillas-Gay, M.I., Hoitink, H.A.J. and Madden, L.V. 1986. Nature of suppression of Fusarium wilt of radish in a container medium amended with composted hardwood bark. Plant Dis. 70:1023-1027.

Tuitert, G., Szczech, M. and Bollen, G.J. 1998. Suppression of Rhizoctonia solani in potting mixtures amended with compost made from organic household waste. Phytopathology 88:764-773.

van Bruggen, A.H.C. and Semenov, A.M. 2000. In search of biological indicators for soil health and disease suppression. Appl. Soil Ecol. 15:13-24.

Weller, D.M., Raaijmakers, J.M., McSpadden, G., Gardener, B.B. and Thomashow, L.S. 2002. Microbial populations responsible for specific soil suppressiveness to plant pathogens. Annu. Rev. Phytopathol. 40:309-348.

Workneh, F. and van Bruggen, A.H.C. 1994. Microbial density, composition, and diversity in organically and conventionally managed rhizosphere soil in relation to suppression of corky root of tomatoes. Appl. Soil Ecol. 1:219-230.

\section{Tables}

Table 1. Correlation (simple) among standardized area under disease progress curve (AUDPCs) of Fusarium wilt and different microorganisms recovered from seven plant growth media (CFU ml ${ }^{-1}$ ).

\begin{tabular}{lccl}
\hline Microorganism group & $\begin{array}{c}\mathrm{R}^{2} \\
(\%)\end{array}$ & $\mathrm{P}^{2}$ & \multicolumn{1}{c}{ Equation } \\
\hline Celullolitic bact. & 87.87 & $* *$ & AUDPCs $=0.5702-0.03144 \cdot \operatorname{Ln}$ (celullolitic bact.) \\
$\Sigma$ bact. & 83.55 & $* *$ & AUDPCs $=0.665-0.03358 \cdot \operatorname{Ln}(\Sigma$ bact.) \\
Oligotrophic bact. & 82.41 & $* *$ & AUDPCs $=0.6388-0.03392 \cdot$ Ln(oligotrophic bact.) \\
Copiotrophic bact. & 80.50 & $* *$ & AUDPCs $=0.927-0.03302 \cdot \operatorname{Ln}$ (copiotrophic bact.) \\
Celullolitic act. & 76.33 & $*$ & AUDPCs $=2.204 \cdot$ celullolitic act. $^{-0.3227}$ \\
$\Sigma$ act. & 70.69 & $*$ & AUDPCs $=3.481 \cdot \Sigma$ act. $^{-0.3318}$ \\
Oligotrophic act. & 70.23 & $*$ & AUDPCs $=1.4446 \cdot$ oligotrophic act. $^{-0.2994}$ \\
Bacillus spp. & 65.32 & $*$ & AUDPCs $=0.4074-0.02396 \cdot \operatorname{Ln}($ Bacillus spp. $)$ \\
\hline
\end{tabular}




\footnotetext{
${ }^{1}$ Bact $=$ bacteria $;$ act $=$ actinomycetes $; \Sigma$ bact $=$ celullolitic, oligotrophic and copiotrophic bacteria; $\Sigma$ act $=$ celullolitic, oligotrophic and copiotrophic actinomycetes.

${ }^{2}$ Significance levels: $* * *$ and $* * *$ indicate $P<0.05,0.01$ and 0.001 , respectively
}

\section{Figures}

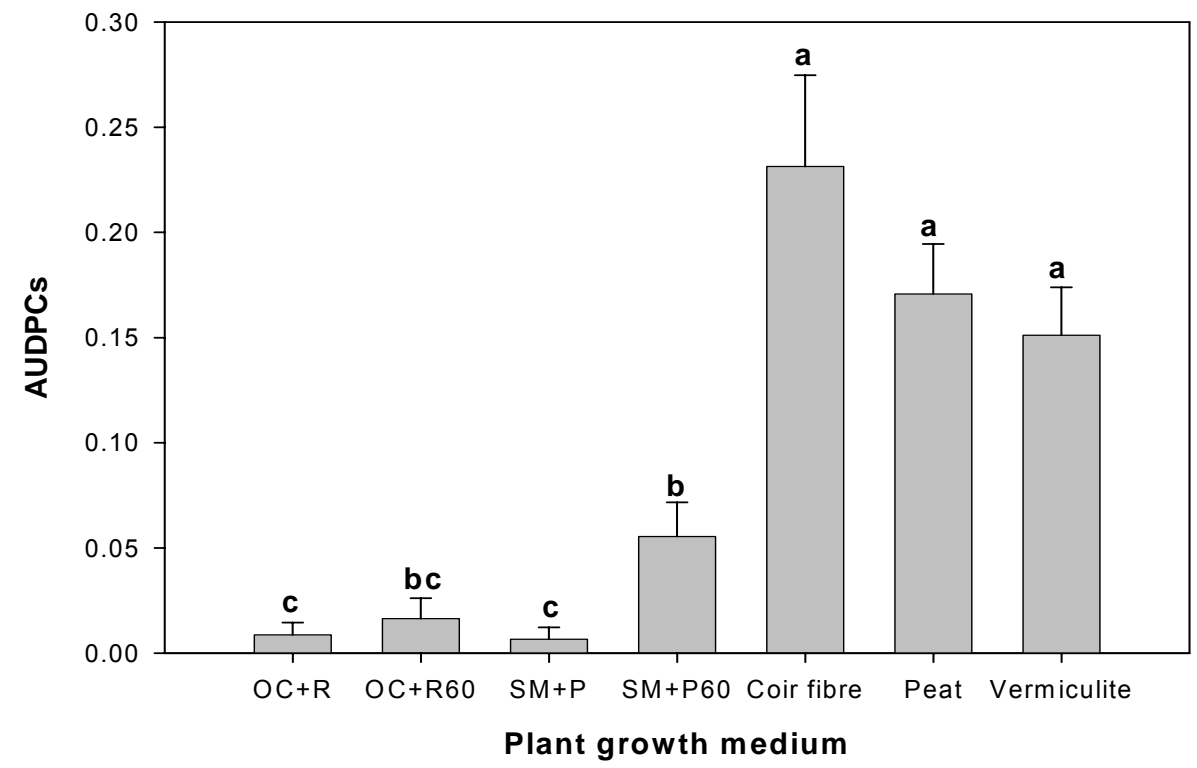

Fig. 1. Standardized area under disease progress curve (AUDPCs) for tomato plants in seven growth media. $\mathrm{OC}+\mathrm{R}$ : olive oil husk + cotton gin trash composted and mixed with rice husk; SM+P: spent mushroom composted and mixed with peat; 60: heated. Disease severity scale was from 0: asymptomatic plants, to 3: dead plants. Plant growth media were infested with Fusarium oxysporum f. sp. lycopersici $\left(10^{5}\right.$ microconidia $\mathrm{ml}^{-1}$ ). Data for AUDPCs were transformed for analysis with the arcsine $\sqrt{\mathrm{x}}$. Bars with the same letter are not significantly different according to Tukey's test at $P<0.05$. Standard error of the mean is indicated by vertical line. 